\title{
Cyberloafing: Minimalizing Work Stress on Millennial Generations Employee
}

\author{
Dita Nurhidayah ${ }^{1 *}$, Caecilia Tri Wahyanti ${ }^{2}$
}

1,2 Universitas Kristen Satya Wacana, Salatiga, Indonesia

\section{ART I CLE IN F O}

\section{Article history:}

Received July 08, 2021

Revised July 10, 2021

Accepted August 12, 2021

Available online August 25, 2021

Keywords:

Cyberloafing Behavior, Work Stress, Millennial Generation Employees

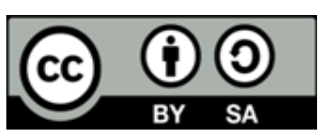

This is an open access article under the CC BY-SA license.

Copyright $(\odot) 2021$ by Author. Published by Universitas Pendidikan Ganesha.

\begin{abstract}
A B S T R A C T
In the era of industry 4.0, technological changes are accelerating rapidly. Internet technology provides many conveniences for employees to deal with their duties. The use of the internet that has become a characteristic of individuals, especially employees, has a negative or positive impact. This study aims to determine the factors that cause cyberloafing behavior in millennial employees, how the impact of cyberloafing behavior, what kind of work stress experienced by millennials and how cyberloafing behavior can minimize work stress in millennial generations. The research method applied is descriptive method with a qualitative approach. The data collection technique used is by conducting interviews with 2 millennial generation employees and 1 leader. The interview technique is done in semi-structured technique and list of questions are prepared for the interview which are developed based on the relevant literature. After the data is obtained, the presentation and data reduction are carried out, then conclusion is drawn. The result of this study indicates that cyberloafing behavior in millennial generation employees is an activity carried out by millennial generation employees to minimize work stress occurred during working hours in the company environment. This means that cyberloafing behavior among millennial generation employees is considered an activity that can refresh brain performance. This behavior is carried out to reduce or minimize the stress experienced such as entertainment when stressed, refreshing the brain from stress and boredom because they have to work continuously.
\end{abstract}

\section{INTRODUCTION}

The internet changes a person's life in getting work done. The use of the internet that has been installed on individuals, especially employees, has a negative impact. One of the negative impacts that often arise is cyberloafing (Jia, 2008; Restubog et al., 2011). Employees who are involved in cyberloafing activities for 2 hours per day are using the internet for their interests (Askew et al., 2014; Betts et al., 2014). This causes organizations to worry about surfing the internet for personal gain because it can ignore work responsibilities. Cyberloafing in the workplace has been recognized as a form of counterproductive behavior that harms organizations (Elrehail et al., 2021; Jandaghi et al., 2015). There are several possibilities for cyberloafing behavior that occurs namely, they experience work stress. Work stress is defined as the pressure felt by employees because of the many tasks they cannot fulfill (Huma et al., 2017). Causes of work stress can be in the form of lack of time in completing the given task, no facilities that support work, and conflicting tasks. One of the behaviors that are considered negative in using the internet at work is the tendency to access sites that are not relevant to work responsibilities, which results in cyberloafing (Blau et al., 2006; Hussain \& Parida, 2017). Cyberloafing not only has a negative impact but can also have a positive impact. Accessing the internet while working can have a positive impact such as increasing creativity, flexibility and fostering a conducive learning environment. Other positive things such as reducing boredom, fatigue, or excessive work stress, and can give employees a sense of happiness (Yaşar \& Yurdugül, 2013).

Cyberloafing is deviant behavior that occurs when employees use various types of computer devices such as gadgets, tablets while working for non-destructive activities where superiors consider the behavior unrelated to work (Bozbayindir, 2019; Rajah \& Lim, 2011). The technology used to carry out cyberloafing can be through office computers or personal devices. There are three causes of employee's cyberloafing, namely the presence of individual factors explaining a person's attitude towards habits, 
internet use, social norms, demographic factors, and individual values at work. The second factor is situational factors that explain whether or not there are conditions that support cyberloafing behavior in the company. The third factor is organizational factors that explain restrictions on internet use, managerial support (telling employees about internet use at work), employee work attitudes, expected consequences, and job characteristics that can influence someone to cyberloafing (Liberman et al., 2011; Ozler \& Polat, 2012).

According to data from the Central Statistics Agency (BPS), the population in Indonesia who is included in the working-age population category is the population aged 15 years and over, while the population included in the labor force category is the population aged 15 years and over. Who has both temporary and temporary jobs unemployed? Based on the categories determined by BPS, the population aged 15 years and over in 2020, the population born in 2005 became residents in the working-age population categories.Workers in an organization or company have different characteristics, because based on the year of birth, in the grouping of workers to date there are five generations, namely traditionalists or the so-called silent generation born between 1928-1944 whose values approach authority. and top management down, baby boomers born between 1945 and 1965 tend to be workaholics, Generation X was born between 1965 and 1979, a generation that is comfortable with authority and sees work-life balance as important, Generation Y born between 1980 and 2000 and generally grow in prosperity and have smart technology, born in the digital world.

The characteristics of the millennial generation in work are much different from previous generations (Blanchard \& Henle, 2008; Derin \& Gökçe, 2016). Millennials are more concerned with opportunities for growth than salaries. Millennials prefer to work for companies that have complete facilities and implement a work-life balance. Millennials tend to prefer to move places of work compared to previous generations. Millennials do not pursue job satisfaction but want to develop themselves in the job (learning new things, new skills, new perspectives, getting to know more people, taking opportunities) to develop, and so on), millennials prefer freedom and flexi-time at work (Demir \& Melek, 2018; Khansa et al., 2018). There is a study in Mental Health Foundation (MHF) that states that the millennial generation has a higher level of work stress than other older generations such as generation X. Millennial generation employees waste twice as much time as babies. Generation Boomers, millennials waste the most time, which is 2 hours a day for things that are not related to work or cyberloafing. Millennial generation employees who experience work stress will try to overcome it, one of which is by cyberloafing but not all employees perform this cyberloafing behavior (Askew et al., 2014; Huma et al., 2017).

Cyberloafing can help employees to deal with stress and work burnout. Employees are human resources who need time to relieve work stress. When employees are productive and happy, it will result in better performance (Blau et al., 2006; Ozler \& Polat, 2012). However, employees should not spend too much time cyberloafing, as this can outweigh the benefits. In addition, employees can get new and fresh perspectives or ideas from cyberloafing. Job stress is a natural thing for employees, and of course, these employees will try to cope with the stress they experience (Derin \& Gökçe, 2016; Liberman et al., 2011). The Covid-19 pandemic has caused a change in behavior in society. This is related to appeals in the form of physical and social distancing, reducing activities outside the home, and reducing places used for gathering people, one of which is the office. One of the changes in the social order in work activities is the concept of working in the form of work from home. From an organizational perspective, the implementation of work from home information technology will certainly reduce office operational costs such as subscription fees and services such as electricity, water, and internet, cleaning costs, as well as the costs of employee needs who will transfer the burden of employees personally. However, the application of the concept of work from home causes a new phenomenon, namely an increase in cyberloafing behavior. This phenomenon occurs because there is no supervision from the company. Surely this can affect the quality of an employee's performance.

In a pre-research interview with two millennial generation employees in the city of Salatiga in February at the position of staff Software Engineer, they said that when the work was finished, the person concerned used his time to open YouTube, social media, and chat rooms via gadgets. There are also employees who have not finished their work but feel bored at work and stressed so that they play with their gadgets to relieve fatigue. Based on the narrative in question, the provision of fast internet facilities and no written regulations regarding the prohibition of playing gadgets supports cyberloafing behavior and sometimes even causes work not to be completed on time. There is research that states that there is a significant positive effect between work stresses on cyberloafing, the higher the work stress, the higher and the cyberloafing level, and vice versa. In contrast to the results research which states that low work stress affects cyberloafing behavior, if we look at role ambiguity, role conflict, and employee role overload. Research on the same results was carried stated that the results showed that work stress had no effect on cyberloafing. 
Based on the description above, most of the previous research explained the effect of work stress on cyberloafing behavior. However, research on cyberloafing behavior related to efforts to minimize work stress on employees has not been widely carried out. In addition, previous research related to cyberloafing behavior and work stress did not use research subjects based on generation criteria. Based on these limitations, the authors conducted research related to cyberloafing behavior and work stress in the millennial generation because it focused on the industrial era 4.0 of technological development and utilizing devices, applications, and functions of internet digital technology. This study aims to analyze the factors that cause cyberloafing behavior in millennial generation employees, how the impact of cyberloafing behavior, what forms of work stress experienced by millennials and how cyberloafing behavior can minimize work stress in millennial generations. So from the problems above, this study aims to find out what factors influence cyberloafing behavior, find out the form of work stress experienced by the millennial generation, and find out how cyberloafing behavior can minimize work stress on millennial generation employees. This research is expected to contribute to the literature in the field of cyberloafing behavior and work stress in the world of work, as well as add insight to the study of human resource management.

\section{METHODS}

Research on cyberloafing behavior as an effort to minimize work stress on millennial generation employees uses a qualitative research approach with descriptive methods (Milles \& Huberman, 1992; Sugiyono, 2014). The type of data that will be used is primary data. Primary data was obtained directly from the results of in-depth interviews. The type of question used in the in-depth interview technique is an openended question. The data analysis technique of this research uses interactive analysis from Miles \& Huberman. Three stages that must be done in analyzing qualitative research data, namely (1) data reduction; (2) data exposure; and (3) drawing conclusions and verification (Milles \& Huberman, 1992). The object of this research is PT. Promanufacture Indonesia Jl. Sukarno Hatta No.14, RT.004/RW.004, Cebongan, Kec. Argomulyo, Salatiga City, Central Java 50736. The criteria for employees who will be as informants are employees of the millennial generation born in 1982-2000, employees who experience work stress, employees who engage in cyberloafing behavior during working hours, using smartphones, PCs, and internet networks. To support work, employees who are actively working for more than one year and are not on leave.

\section{RESULTS AND DISCUSSIONS}

\section{Results}

Based on interviews with three different millennial resource persons related to cyberloafing behavior as an effort to minimize work stress on millennial generation employees, there are several similarities in answers to the questions asked such as cyberloafing behavior activities caused by several factors, namely the perception and attitude of employees that cause the habit of using from oneself to do cyberloafing, secondly there are those who support cyberloafing behavior in the workplace, because of the characteristics of jobs that require an internet network and there are no written rules or restrictions regarding the use of devices and the internet during working hours. Caused by several factors, namely because the characteristics of the work of a software engineer must always be connected to the internet network to access the platform used as a software engineer. Communication media while working in the company. The second factor is related to the characteristics of the job causing the opportunity for informants to cyberloafing during working hours. The third factor is the attitude factor of using electronic media and internet networks from individuals causing the habit of using oneself to do cyberloafing. This cyberloafing activity takes quite a long time. Work stress is defined as the burden and pressure felt by employees because of the pressure or encouragement that they must fulfill by the time and results that have been determined. This was confirmed by informant R3 as a leader in the software engineering section that job characteristics are closely related to the internet and there is no limit to cyberloafing behavior because it is not considered a violation.

This cyberloafing behavior is carried out because work stress that occurs continuously and uncontrollably causes physical fatigue, according to informant R2. The cyberloafing behavior of millennial generation employees cannot be separated from positive and negative impacts. The positive impacts of cyberloafing behavior among millennial generation employees are: first, this behavior refers to brain performance, for millennial employees' cyberloafing is considered an activity that can refresh brain performance. Second, as a source of information, third, as entertainment when stressed and refresh the brain from stress or boredom from having to work continuously, fourth, increasing productivity. 
According to informants R1 and R2, the negatives are first: time and time, forming a habitual attitude that is carried out continuously, lack of employee initiative at work. Second: cyberloafing behavior causes employees to neglect their obligations in carrying out company duties, resulting in delayed work behavior. As a form of stabilization effort to neutralize his physical condition back to normal. One of the activities without having to leave the desk is surfing in cyberspace, for example accessing social networks, online games, and online chatting, this activity is cyberloafing. According to informant R1, this cyberloafing behavior occurs because employees have internet access at their desks. This is under the results of the study, informants revealed that cyberloafing occurs when employees have internet access at their desks. This behavior is carried out to reduce or experience stress experienced such as entertainment when stressed, refreshing the brain from stress and boredom because it has to be continuous.

\section{Discussion}

\section{Factors that influence cyberloafing behavior}

The results of this study, the factors that influence the behavior of cyberloafing are influenced by several things, namely the habitual attitude of using individuals to carry out cyberloafing behavior. The results of the interview show that the average millennial employee accesses sites that are not related to their work for approximately 2-3 hours in 1 day. This means that the activities of employees to access the internet during working hours become a habit and cause them to abuse the internet every day. As for other cyberloafing behavior, namely accessing the internet during working hours every day by opening online shopping sites such as shopee, and online video sites such as YouTube. The second is organizational factors, the characteristics of the work that employees do are always related to electronic media and are always connected to the internet network (Ardilasari, 2017; Romadhani, 2020). The characteristics of the job provide an opportunity to do cyberloafing during working hours, this is following the results of interviews of researchers with informants that informants often listen to music during working hours, this behavior is carried out because of work as software engineering requires concentration. In addition to this, there are no restrictions on certain sites in the use of the internet network, including organizational factors. The third factor is situational factors, the absence of written rules regarding the prohibition of using the internet network causes employees to cyberloafing this occurs because there are no control measures for cyberloafing behavior.

Third, cyberloafing tends to be done when no workload accumulates and there is excessive free time. More working hours and completed work can lead to cyberloafing behavior. Cyberloafing is carried out as a form of utilizing free time while waiting for work hours to finish. The use of this free time can be used by employees to fulfill various personal needs that can be done online behind the desk. Stress at work is a natural thing for employees, and from the symptoms of individuals who experience work stress, employees will try to overcome the stress they experience, one of which is cyberloafing. Several factors influence cyberloafing behavior, namely individual factors, including employee perceptions and attitudes, personal traits, employee normative beliefs, and demographics. Like employees can be seen attitudes such as shyness, loneliness, self-management of the surrounding environment, self-esteem, isolation, and locus of control can affect cyberloafing behavior in employees. Organizational factors, expected to be in the application of the internet, are expected, managerial support, views of colleagues regarding cyberloafing behavior norms, employee work attitudes, employee job characteristics. Situational factors, control measures for cyberloafing behavior, usually occur when employees have access to the internet at work so they can be influenced by situational factors (Blanchard \& Henle, 2008; Demir \& Melek, 2018).

\section{Impact of Cyberloafing Behavior}

Cyberloafing behavior in millennial employees cannot be separated from positive and negative impacts. The results of this study produce information about the impact of cyberloafing behavior among millennial generation employees, namely: first, this behavior refers to brain performance, for millennial employees cyberloafing is considered an activity that can refresh brain performance. Second, as a source of information, third, as entertainment when stressed and refresh the brain from stress or boredom from having to work continuously, fourth, increasing productivity. Other positive impacts such as reducing boredom, fatigue, or excessive work stress, and can give employees a sense of happiness. Many parties do not agree that cyberloafing is always bad. The millennial employees in this study explained that the internet provides an indispensable platform for flexibility and fosters a conducive environment in the workplace (Derin \& Gökçe, 2016; Liberman et al., 2011). According to data obtained from interviews regarding cyberloafing, the most frequent cyberloafing behavior by millennial employees of company $\mathrm{X}$ is receiving or sending instant messages such as Whatsapp, visiting websites about current news such as kompas.com, detik.com, Kapanlagi.com, and visit social networks such as Instagram, and YouTube. The results of this study are following the theory. The era of technology as it is today requires employees to always be up-to- 
date. Humans as social beings need to communicate with other people. By following the trend of how to communicate through instant messages and social networks, millennial employees of company $\mathrm{X}$ can communicate easily, both with family, relatives, and friends. In addition, employees also need to get information about the news that is happening to add insight.

The negative impacts are: time-consuming, cyberloafing activities spend approximately 2 hours surfing on social media, this activity becomes a habit that is carried out continuously, resulting in a lack of employee initiative at work. Cyberloafing behavior causes employees to neglect their obligations in carrying out company duties, resulting in work delays, which will have an impact on employee performance. Cyberloafing in the workplace has been recognized as a form of counterproductive behavior that endangers the organization (Dursun et al., 2018; Khansa et al., 2018; Yllmaz et al., 2015).

\section{The form of work stress experienced by the millennial generation}

The form of work stress experienced by millennial generation employees during the first work, namely the demands of the role, this work stress is related to the pressure given to employees who play a role in an organization. According to the informant, this work stress occurs because of a close deadline but there are frequent changes in requirements. Second, the existence of interpersonal demands, this form of work stress is related to the pressure created by other employees. Some factors occur due to the unexpected. This form of work stress is in the form of shifting the delegation of tasks that are joint responsibility in the team due to the condition of the employee who falls ill, this situation causes excessive work stress (Astri, Y. \& Zahreni, 2018; Sawitri, 2012).

There is pressure and demands from superiors regarding projects that must be done according to requests from customers, this is related to business flow, but causes work stress on employees because of the high level of urgency causing pressure and time demands from superiors. Fourth, there are demands for tasks that must be completed, according to the work stress informants experienced because there is a lot of work to be done, but the work is not finished, this condition causes work stress because every day you have to work and it happens again and again. The results of this study strengthen previous studies which revealed that there are a number of working conditions that often cause stress for employees, including excessive workload pressure or time pressure (Azizah \& Setyawati, 2019; Hurriyati, 2017). There are many factors in an organization that can cause stress. Pressure to complete tasks in a tight time, excessive workloads, customer demands that are always demanding and the level of project urgency is close. Millennial employees at company $\mathrm{X}$ tend to have a positive perception of the job description, they view the tasks given as a risk to their work and are considered to be able to improve their abilities and stimulate positive emotions to be more productive at work. Other data found in this study is that the average millennial employee at company $\mathrm{X}$ feels that too much workload is a factor that causes them to experience work stress. The results of this study strengthen previous studies which revealed that there are a number of working conditions that often cause stress for employees, including excessive workload pressure or time pressure (Demir \& Melek, 2018; Liberman et al., 2011).

The unfinished workload causes excessive work stress and has an impact on the psychological condition of employees. Work stress is defined as the burden and pressure felt by employees because of the pressure or encouragement that they must fulfill in accordance with the specified time and results. Work stress that occurs continuously and uncontrollably causes physical, psychological, and emotional fatigue. The work stress experienced is being lazy to go to the office because of repetitive routines, according to the informant, when employees cannot control work stress, performance will fall apart. The impact is psychological and emotional fatigue such as falling sick, dizziness, fever, and others. However, because the work system in the company is flexible, millennial employees prefer to go to work later than working hours in general, this is done so that psychologically and emotionally improve. The results of this study indicate that there is an impact of work stress on the psychology and emotions of millennial generation employees, but it is necessary to know that there is work stress that has a good impact on employee performance, this is due to work pressure on employees which makes work motivation increase. Stimuli that are too small, challenges and challenges that leads to boredom, frustration, and lack of maximum use of abilities. However, based on the results of the study, the informant stated that the presence of pressure and time can direct the ability to meet work needs and become a healthy stimulus for employees to overcome work challenges (Rajah \& Lim, 2011; Yılmaz et al., 2015).

Work stress, performance tends to increase because job stress helps employees to direct all resources in meeting work needs, is a workplace that encourages employees to respond to work challenges. Finally, job stress reaches a stable point which is approximately by the employee's performance ability. Furthermore, if work stress becomes too great, performance will begin to decline because work stress interferes with the implementation of work. Employees lose the ability to control it. The most extreme 
consequences are zero performance, employees can no longer work, despair, or refuse to work to avoid work stress.

\section{Cyberloafing behavior can minimize work stress}

The results of this study indicate that individuals who experience work stress can be reflected in several symptoms including loss of enthusiasm and energy, increased emotional tension, irritability and aggression, unable to relax, lazy at work. Work stress experienced by millennial generation employees is due to work demands that trigger psychological fatigue, such as too much workload and limited time given to complete the work (Ardilasari, 2017; Blanchard \& Henle, 2008). When an employee is stressed, the employee's psyche will also respond to the stress experienced. This results in changes in the psyche of employees to become exhausted, for example, such as working non-stop for long working hours, too much workload and limited time is given to complete the work, and conflicts in the demands of work that must be completed.

When employees are aware of various unpleasant changes in physical conditions as a result of work stress and can affect their performance at work, employees will carry out other activities as a form of stabilization effort to neutralize their physical condition back to normal. One of the activities without having to leave the desk is to surf in cyberspace, for example accessing social networks, online games, and chatting online. This behavior includes cyberloafing. This cyberloafing behavior occurs because employees have internet access at their desks. This is under the results of the study, informants revealed that cyberloafing occurs when employees have internet access at their desks. This results in every employee having the opportunity to use the internet facility for personal interests that are not related to work. With the reason to be able to return to work with the maximum as usual. Cyberloafing activities for employees that are useful as entertainment. This study resulted in the fact that cyberloafing behavior can cause work stress experienced by employees (Liberman et al., 2011; Yllmaz et al., 2015).

Millennial employees at company X consider one of the fun activities to relieve work stress is cyberloafing. A fun activity to fill when stressed and bored at work is using the internet during working hours such as accessing Facebook, YouTube, WhatsApp, Instagram, Shopee and various other sites. Apart from work stress, cyberloafing tends to be done when no workload accumulates and there is excess free time. Cyberloafing is carried out as a form of utilizing free time while waiting for work hours to finish. The use of this free time can be used by employees to fulfill various personal needs that can be done online behind the desk. Cyberloafing is one way for employees to deal with stress. Cyberloafing as the action of company employees using internet access during working hours to open the web that is not related to work for personal purposes. Cyberloafing is categorized as emotion-focused coping. Emotion-focused coping is an effort to deal with stress by regulating emotional responses to adjust to the impact that will be caused by a condition or situation that is considered stressful and is done by avoiding or breaking away from stressors, such as sleeping, eating, drinking, and smoking. From the explanation above, it can be seen that someone who experiences work stress will have a great desire to overcome the stress they experience, one of which is by doing cyberloafing. This means that cyberloafing behavior among millennial generation employees is considered an activity that can refresh brain performance, this behavior is carried out to reduce or create stress experienced such as entertainment when stressed, and refreshing the brain feeling stressed and bored because they have to work continuously, and has an impact on increased productivity of employee performance (Betts et al., 2014; Dursun et al., 2018; Elrehail et al., 2021).

\section{CONCLUSION}

Cyberloafing behavior is an effort to overcome stress by regulating emotional responses to adapt to the impact that will be caused by a condition or situation that is considered stressful and is carried out by avoiding or breaking away from stressors, such as sleeping, eating, drinking, and smoking. Someone who experiences work stress will have a great desire to overcome the stress they experience, one of which is cyberloafing. This means that cyberloafing behavior among millennial generation employees is considered an activity that can refresh brain performance. This behavior is carried out to reduce or minimize the stress experienced such as entertainment when stressed, refreshing the brain from stress and boredom because they have to work continuously.

\section{REFERENCES}

Ardilasari, N. (2017). Hubungan Self Control Dengan Perilaku Cyberloafing Pada Pegawai Negeri Sipil. Jurnal Ilmiah Psikologi Terapan, 5(1), https://ejournal.umm.ac.id/index.php/jipt/article/view/3882. 
Askew, K., Buckner, J. E., Taing, M. U., Ilie, A., Bauer, J. A., \& Coovert, M. D. (2014). The role of the theory of planned behavior. Computers in Human Behavior, 36, 510-519. https://doi.org/10.1016/j.chb.2014.04.006.

Astri, Y., \& Zahreni, S. (2018). Pengaruh Iklim Organisasi terhadap Perilaku Cyberloafing pada Karyawan PT X: Effect of Organization Climate on Cyberloafing Behavior in Employees of PT X. Psikologia: Jurnal $\begin{array}{llll}\text { Pemikiran Dan Psikologi, 16-26. } & \end{array}$ https: //talenta.usu.ac.id/jppp/article/view/2264.

Azizah, S. N., \& Setyawati, H. A. (2019). Cyberloafing sebagai strategi mengatasi kebosanan kerja. Fokus Bisnis: Media Pengkajian Manajemen Dan Akuntansi, 18(1), 1-7. http://www.journal.stieputrabangsa.ac.id/index.php/fokbis/article/view/301.

Betts, T. K., Setterstrom, A. J., Pearson, J. M., \& Totty, S. (2014). Explaining cyberloafing through a theoretical integration of theory of interpersonal behavior and theory of organizational justice. Journal of Organizational and End User Computing (JOEUC), 26(4), 23-42. https://www.igiglobal.com/article/explaining-cyberloafing-through-a-theoretical-integration-of-theory-ofinterpersonal-behavior-and-theory-of-organizational-justice/119505.

Blanchard, A. L., \& Henle, C. A. (2008). Correlates of different forms of cyberloafing: The role of norms and external locus of control. Computers in Human Behavior, 24(3), 1067-1084. https: //doi.org/10.1016/j.chb.2007.03.008.

Blau, G., Yang, Y., \& Ward-Cook, K. (2006). Testing a measure of cyberloafing. Journal of Allied Health, 35(1), 9-17.

https://www.ingentaconnect.com/content/asahp/jah/2006/00000035/00000001/art00003.

Bozbayindir, F. (2019). The Relationship between the Time Management Skills and Cyberloafing Behavior of School Administrators: A Quantitative Analysis. Educational Policy Analysis and Strategic Research, 14(3), 178-199. https://eric.ed.gov/?id=EJ1232184.

Demir, M., \& Melek, T. A. N. (2018). Relationship between demographic characteristic of employees and cyberloafing behavior. Journal of Tourism Theory and Research, 4(1), 40-56. https: //dergipark.org.tr/en/pub/jttr/article/375791.

Derin, N., \& Gökçe, S. G. (2016). Are cyberloafers also innovators?: A study on the relationship between cyberloafing and innovative work behavior. Procedia-Social and Behavioral Sciences, 235, 694-700. https://doi.org/10.1016/j.sbspro.2016.11.070.

Dursun, O. O., Donmez, O., \& Akbulut, Y. (2018). Predictors of cyberloafing among preservice information technology teachers. Contemporary Educational Technology, 9(1), 22-41. https://dergipark.org.tr/en/pub/cet/issue/34282/378820.

Elrehail, H., Rehman, S. U., Chaudhry, N. I., \& Alzghoul, A. (2021). Nexus among cyberloafing behavior, job demands and job resources: A mediated-moderated model. Education and Information Technologies, 26, 4731-4749. https: //doi.org/10.1007/s10639-021-10496-1.

Huma, Z. -e., Hussain, S., Thurasamy, R., \& Malik, M. I. (2017). Determinants of cyberloafing: a comparative study of a public and private sector organization. Internet Research, 27(1), 97-117. https: //doi.org/10.1108/IntR-12-2014-0317.

Hurriyati, D. (2017). Analisis Faktor-Faktor Yang Mempengaruhi Perilaku Cyberloafing Pada Pegawai Negeri Dinas Pekerjaan Umum Kota Palembang. Jurnal Ilmiah Psyche, 11(2), 75-86. http://journal.binadarma.ac.id/index.php/jurnalpsyche/article/view/40.

Hussain, S., \& Parida, T. (2017). Exploring cyberloafing behavior in South-central Ethiopia: A close look at Madda Walabu University. Journal of Media and Communication Studies, 9(2), 10-16. https://doi.org/10.5897/JMCS2016.0499.

Jandaghi, G., Alvani, S. M., Zarei Matin, H., \& Fakheri Kozekanan, S. (2015). Cyberloafing management in organizations. Iranian Journal of Management Studies, 8(3), 335-349. https://doi.org/10.22059/ijms.2015.52634.

Jia, H. H. (2008). Relationships between the big five personality dimensions and cyberloafing behavior. Southern Illinois University at Carbondale.

Khansa, L., Barkhi, R., Ray, S., \& Davis, Z. (2018). Cyberloafing in the workplace: mitigation tactics and their impact on individuals' behavior. Information Technology and Management, 19(4), 197-215. https://doi.org/10.1007/s10799-017-0280-1.

Liberman, B., Seidman, G., McKenna, K. Y., \& Buffardi, L. E. (2011). Employee job attitudes and organizational characteristics as predictors of cyberloafing. Computers in Human Behavior, 27(6), 2192-2199. https://doi.org/10.1016/j.chb.2011.06.015.

Milles, M. B., \& Huberman, A. M. (1992). Analisis Data Kualitatif (T. R. Rohidi \& Mulyarto (eds.)). Universitas Indonesia Press.

Ozler, D. E., \& Polat, G. (2012). Cyberloafing phenomenon in organizations: Determinants and impacts. 
International Journal of EBusiness and EGovernment Studies, 4(2), 1-15. https://dergipark.org.tr/en/pub/ijebeg/issue/26199/275855.

Rajah, R., \& Lim, V. K. (2011). Cyberloafing, Neutralization, And Organizational Citizenship Behavior. PACIS, 152, 24-40. https://aisel.aisnet.org/cgi/viewcontent.cgi?article=1151\&context=pacis2011.

Restubog, S. L. D., Garcia, P. R. J. M., Toledano, L. S., Amarnani, R. K., Tolentino, L. R., \& Tang, R. L. (2011). Yielding to (cyber)-temptation: Exploring the buffering role of self-control in the relationship between organizational justice and cyberloafing behavior in the workplace. Journal of Research in Personality, 45(2), 247-251. https://doi.org/10.1016/j.jrp.2011.01.006.

Romadhani, R. K. (2020). Anteseden Cyberloafing pada Karyawan Perusahaan Start-up. Acta Psychologia, 2(2), 173-182. https://journal.uny.ac.id/index.php/acta-psychologia/article/view/35104.

Sawitri, H. S. R. (2012). Interaksi tekanan pekerjaan dan komitmen pada perilaku cyberloafing karyawan. Media Riset B \& Manajemen, 12(2), 91-107. http://www.trijurnal.lemlit.trisakti.ac.id/mrbm/article/view/1107http://www.trijurnal.lemlit.tr isakti.ac.id/mrbm/article/view/1107.

Sugiyono. (2014). Metode Penelitian Pendidikan Pendekatan Kuantitatif, Kualitatif, dan R\&D. Alfabeta.

Yaşar, S., \& Yurdugül, H. (2013). The investigation of relation between cyberloafing activities and cyberloafing behaviors in higher education. Procedia-Social and Behavioral Sciences, 83, 600-604. https://doi.org/10.1016/j.sbspro.2013.06.114.

Yılmaz, F. G. K., Yılmaz, R., Öztürk, H. T., Sezer, B., \& Karademir, T. (2015). Cyberloafing as a barrier to the successful integration of information and communication technologies into teaching and learning environments. Computers in Human Behavior, 45, 290-298. https: //doi.org/10.1016/j.chb.2014.12.023. 